\title{
Prevention of recidivism: experience and innovations
}

\author{
Nadezhda Aleksandrovna Krainova $^{1^{*}}$, Artem Gennadievich Khlebushkin ${ }^{1}$, and Dimitri \\ Oleynik $^{2}$ \\ ${ }^{1}$ Saint Petersburg State University of Economics, Faculty of Law, Department of Criminal Law and \\ Criminal Procedure, Saint Petersburg, Russia \\ ${ }^{2}$ University of Wismar - University of Applied Sciences: Technology, Business and Design, \\ Department of Economic Sciences, Wismar, Germany
}

\begin{abstract}
The state of recidivism indicates that the theoretical, legislative and law enforcement issues of its prevention is still relevant. There are different levels and directions of this warning. When developing and implementing appropriate measures, it is necessary to consider the current situation and existing opportunities in a particular state, the positive experience accumulated in it, the practices implemented in other countries, as well as the prospects for development. This study was conducted to reveal the opinions of convicts and employees of the Federal Penitentiary Service of Russia on certain issues of preventing recidivism, as well as to develop proposals for improving measures aimed at this prevention, with regard to the state of recidivism. The study analyzed and summarized official statistical data, conducted a questionnaire survey of convicts and employees of the Federal Penitentiary Service of Russia, studied the experience of other countries in the sphere of the penitentiary and post-penitentiary impact on convicts, and studied the results of studies conducted by other authors. The work presents the results of the analysis and synthesis of statistical data on recidivism over a long period, as well as the data of the author's survey, and articulates specific proposals for changing existing and new developing measures to prevent recidivism.
\end{abstract}

Keywords: recidivism, re-socialization, punishment, crime prevention

\section{Introduction}

Recidivism was, is and will be the object of close attention from specialists engaged in the study of the causes of crime and the development of a system to counter this negative phenomenon, both domestic and foreign. The article considers, in particular, the state of such crime [1], its types [2], the impact on the recidivism of education and employment [3,4], and other issues related to recidivism [5-7].

The recommencement of criminal behavior on the part of persons who have already been subjected to measures of state influence in the form of punishment, indicates, among others,

\footnotetext{
* Corresponding author: kraynova.n@unecon.ru
} 
that society rejects such persons, there is no or insufficiently effective system of influence and treatment of previously convicted persons.

\section{Results}

A study of the dynamics of recidivism over the past 20 years reveals an almost steady increase in such crime (excluding a slight decrease in the last few years). Thus, according to the data presented on the official website of the Ministry of Internal Affairs of the Russian Federation [8], in comparison with the general data on registered crimes, the number of which shows a downward trend, the recidivism curve is mainly growing, which indicates a deterioration in the structure of crime.

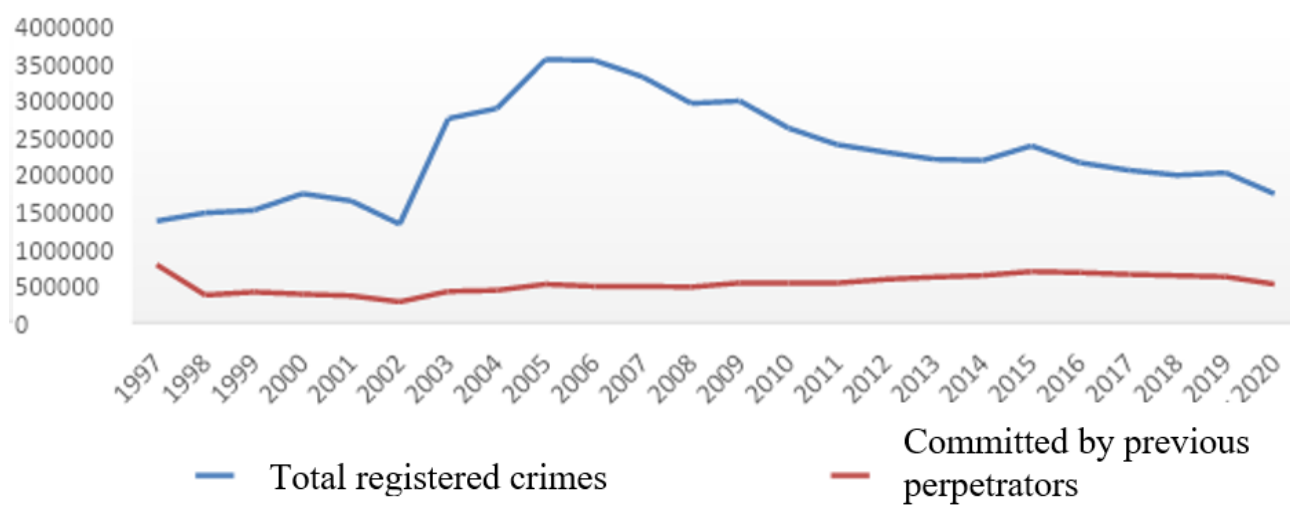

Fig. 1. Dynamics of crime in the Russian Federation in relation to recidivism (absolute data).

The data on the growth of recidivism in Russia is also confirmed by the results of our expert survey. Thus, $70 \%$ of the interviewed employees of the FKU IK-6 of the Federal Penitentiary Service of the Russian Federation for St. Petersburg and the Leningrad Region (a total of 50 employees were interviewed) confirmed an increase in recidivism, while the remaining $30 \%$ found it difficult to answer, and none of the respondents noted a decrease in this indicator. Other researchers provide similar data [9].

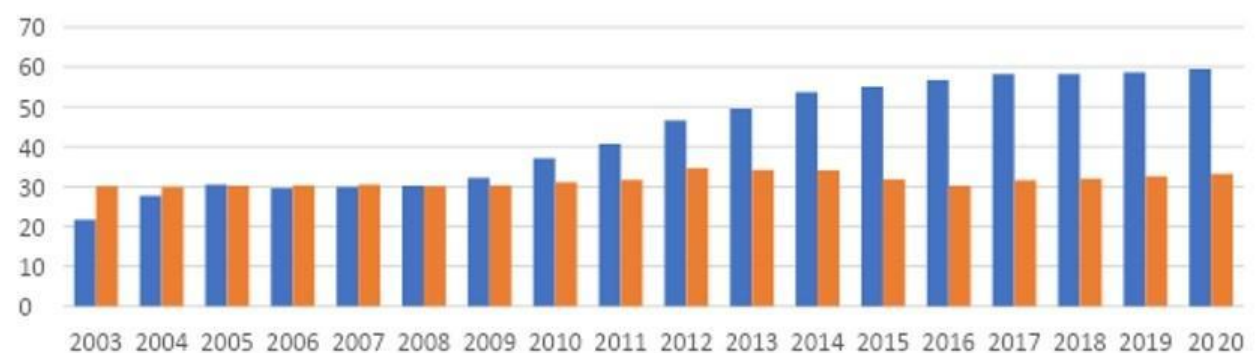

200320042005200620072008200920102011201220132014201520162017201820192020

Proportion at by persons previously perpetrators
Proportion at previously convicted

Fig. 2. Dynamics of the proportion of crimes committed by persons previously committed crimes / previously convicted persons, $\%$.

Recidivism shows a clear tendency to increase and is already half of all detected crimes. If this trend continues, by 2035 recidivism rates of $70 \%$ can be predicted. 
At the same time, the dynamics of the number of crimes committed by previously convicted persons shows relative stability and even a slight tendency to increase, which may indicate a deterioration in the structure of crime.

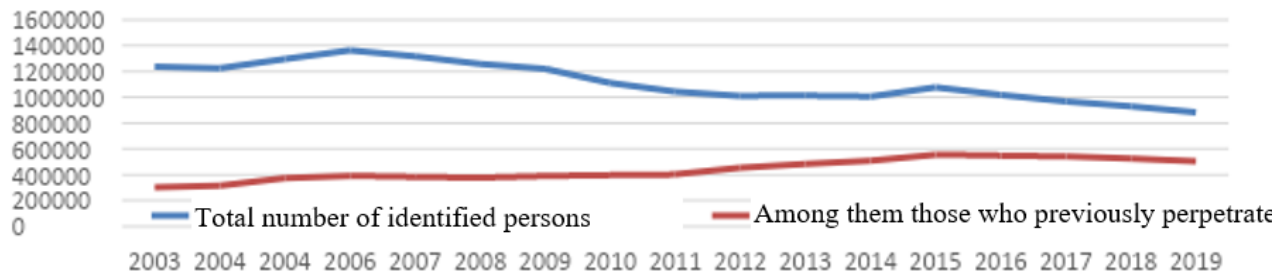

Fig. 3. Dynamics of the number of identified persons who committed crimes, compared to the number of identified persons who previously committed crimes (absolute data).

The dynamics of the number of identified perpetrators of crimes reveals a downward trend, but the number of persons who committed crimes repeatedly, is growing. The curve of the proportion of previously committed and previously convicted persons in the overall structure of crime in Russia looks significant.

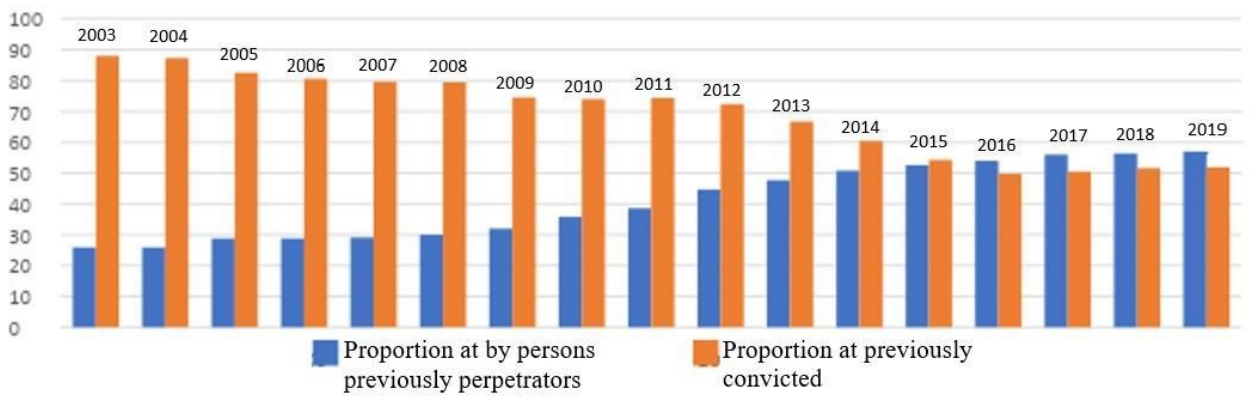

Fig. 4. Dynamics of the proportion of persons previously convicted/previously committed crimes, $\%$.

The share of previously convicted persons in the total number of identified criminals over the past 17 years is generally decreasing, but in 2017-2019 there is a slight increase. At the same time, in the structure of crime, the share of persons who committed crimes earlier is steadily growing.

The negative scenario of the development of the situation with recidivism in Russia is caused by a whole complex of reasons, which include social and economic reasons which currently prevail [10]. But, first of all, statistics on recidivism indicate the effectiveness of the penitentiary system and the implementation of policies in the sphere of post-penitentiary treatment of former convicts.

\section{Discussion}

The conducted research reveals that convicts often do not consider the imposed sentence fair, consider the punishment excessive. Thus, according to a questionnaire survey of convicts held in the FKU IK-6 of the Federal Penitentiary Service of the Russian Federation for St. Petersburg and the Leningrad Region (a total of 300 convicts interviewed), 51\% of convicts believed that the sentence was not fair, while 38\% assessed the sentence as fair, $11 \%$ found it difficult to answer. It seems that this situation is largely due to some "automatism" of the processes associated with the investigation of a crime, and sentencing by the state authorities. Most of the crimes are considered by the courts in a special procedure of judicial proceedings 
with the consent of the accused, which facilitates the judicial procedure, but does not contribute to the re-socialization of the convicted. According to the Judicial Department of the Russian Federation, in the first half of 2020, out of 92,141 convicted persons, cases against $50029(54.29 \%)$ were considered through a special procedure [11].

Meanwhile, the prevention of recidivism will not be effective without regard to the reasons of the ineffectiveness of the previous criminal impact. Criminal punishment should be perceived by the convicted person as an adequate measure for the committed crime, necessary and sufficient to demonstrate to the person the inexpediency of committing crimes in the future. The high level of repeated crimes indicates, among others, that the preventive effect of punishment does not have the proper effect, i.e. "does not work".

For quite a long time, the literature has indicated the main areas of prevention of recidivism: assistance to persons released from serving their sentences, the continuation (consolidation) of their correction, control of their behavior [12]. These areas do not lose their relevance today.

It is now understood in every country where the prison system exists that, in order to prevent recidivism, a person shall be subject to a post-penitentiary influence in order to prevent him/her from returning to a criminal lifestyle. In foreign countries, this process is referred to as treatment. For example, the Spanish legislation provides tratamiento, which includes medical and preventive care, training, education, work, socio-cultural, entertainment and sports activities of prisoners, i.e., the comprehensive development of their personality and providing them with effective tools for life in freedom [13].

The experience of countering recidivism in the UK proves the effectiveness of the employment of convicts at the stage of serving their sentences. Prisoners in the prisons of England and Wales can start working while in a prison facility, using the "one-day release" options agreed with their employers, and continue working after they are released from their sentence [14].

Among the characteristics of foreign penitentiary systems in general, there are several types of production and the ability of convicts to choose their occupation [15].

In the United States, some states are actively implementing special programs aimed at preventing crime. For example, the program the Minnesota's Challenge Incarceration Program (CIP), implemented in relation to those convicted of nonviolent crimes and crimes against property [16].

Such programs involve the active participation of non-governmental organizations and individuals in the form of voluntary activities. The experience of volunteering in some countries is considered to be very successful. For example, experts say that "over the past 13 years, Japan has experienced a boom in voluntary activities aimed at preventing crime; about 3,000,000 Japanese citizens have participated in volunteer activities for this purpose" [17].

Also in the United States, the Seattle's Law Enforcement Assisted Diversion (LEAD) program is implemented, which involves the provision of suspects of drug and prostitutionrelated crimes with certain types of assistance to prevent recidivism [18, 19].

The experience of preventing recidivism in Canada demonstrates the effectiveness of the Correctional Service, which, having comprehensive information about the convicted person, received "from the police, the court, the family members of the offender, his/her employers, psychologists and sometimes even the victim of the crime", develops an individual plan for the correction of the offender, including various kinds of re-socialization measures [14]. The experience of individual programs of work with convicts, implemented even at the stage of serving a sentence, with regard to the peculiarities of adaptation of convicts to the conditions of imprisonment, is also used in China [20].

Among the measures proposed in the scientific works of authors from the CIS countries, there is an idea of creating a "Center for legal, socio-psychological assistance and prevention of recidivism" in the Republic of Belarus [21]. 
In our country, the formation of a system of social rehabilitation of citizens released from prison is implemented by the Concept of Long-term Socio-economic Development of the Russian Federation for the period up to 2020 [22]).

The Russian Federation, with regard to the foreign experience of combating recidivism, is on the path of creating a probation service. Thus, the Ministry of Justice has developed a draft Federal Law "On probation in the Russian Federation and the system of agencies and organizations that implement it" [23]. However, this law has not yet been adopted.

The establishment and operation of re-socialization centers also require appropriate legal support. In theory, the draft law on the basics of providing post-penitentiary assistance to persons released from prison is also proposed [24].

Currently, in the Russian Federation, since 2011, administrative supervision of persons released from punishment has been applied as a measure of post-penitentiary control [25]. The researchers pay attention to the ambiguity of the practical implementation of such a measure [23]. The conducted research has confirmed a certain pessimism of the employees of the Federal Penitentiary Service in terms of the effectiveness of administrative supervision as a means of preventing recidivism. Of the interviewed employees of the FKU IK- 6 of the Federal Penitentiary Service of the Russian Federation for St. Petersburg and Leningrad region, $65 \%$ did not consider administrative supervision an effective measure to prevent recidivism, $10 \%$ considered this measure effective and $25 \%$ of respondents could not answer.

It is believed that during the period of application of administrative supervision in the Russian Federation and the USSR [26], this measure has increasingly realized its potential and has proven itself positively.

However, it also needs to be improved. Thus, similar to foreign practice, administrative supervision in Russia could be divided into preventive and strict. Strict administrative supervision of a certain category of persons (for example, pedophiles) could be established for life. Preventive administrative supervision could be simplified in terms of procedure, the scope of discretion for competent employees performing supervision could be expanded, and special databases of criminals could be created. For example, in the United States, due to the creation of a national system for registering sex offenders, it is possible to track and monitor approximately 800,000 persons [27]. The system of administrative supervision in Russia could be made on the basis of big data technologies, the use of technical means to track the movements of supervised persons.

\section{Conclusion}

The conducted research allows making the following conclusions:

1) statistics show that the situation with the level of recidivism requires increased attention from society and the state;

2) an important prerequisite for the prevention of recidivism is the appointment of a just punishment, since this determines the correct perception by the convict of the correctional impact, which requires proper individualization of responsibility when passing a sentence;

3) there should be a systematic application of the necessary preventive measures in three areas: assistance to persons released from punishment, the continuation and consolidation of their correction, and control over their behavior;

4) It seems appropriate to create re-socialization Centers subordinate to the Ministry of Justice of the Russian Federation to ensure the post-penitentiary adaptation of persons released from punishment;

5) it is necessary to consider the foreign practice of preventing recidivism that has proven its effectiveness;

6) administrative supervision may be divided into two types (preventive and strict) and performed with the use of technical means. 


\section{References}

1. N.V. Pavlovskaya, Bul. Univ. Prosecutor's Office of the RF 6, 24-28 (2019)

2. I.V. Dvoryanskov, O.A. Burkina, A.I. Kuznetsov, A.A. Ustinov, A.G. Emelyanova, M.Yu. Titanov, Rus. J. Crim. 4, 748-760 (2017). https://doi.org/10.17150/25004255.2017.11(4).748-760

3. R. Bozick, J. Steele, L. Davis, S. Turner, J. Experim. Crim. 14, 389-428 (2018). https://doi.org/10.1007/s11292-018-9334-6

4. M. Denver, G. Swach, S.A. Bushway, Crim. 55, 174-204 (2017). https://doi.org/10.1111/1745-9125.12130

5. A. Iudici, F. Boccato, E. Faccio, Int. J. Crim., Justice and Soc. Dem. 7(1), 60-75 (2018). https://doi.org/10.5204/ijcjsd.v7i1.356

6. A. LaCourse, S.J. Listwan, S. Reid, J.L. Hartman, Crime \& Delinquency 65(1), 46-68 (2019). https://doi.org/10.1177/0011128718790497

7. L. Liu, Crime \& Delinquency 66(6-7), 864-886 (2020). https://doi.org/10.1177/0011128719901106

8. Statisticheskie dannye o sostoyanii prestupnosti v RF [Statistical data on the state of crime in the Russian Federation]. Accessed on: March 20, 2021. [Online]. Available: https://мвд.pф/Deljatelnost/statistics

9. E.K. Volkonskaya, Bul. Voronezh Inst. of the Min. of Internal Aff. of Rus. 4, 63-68 (2014)

10. F.V. Grushin, Rus. J. Crim. 11(4), 688-695 (2017). https://doi.org/10.17150/25004255.2017.11(4)

11. Otchet o sostave osuzhdennykh, meste soversheniya prestupleniya [Report on the composition of the convicts, the place of the crime]. Accessed on: March 20, 2021. [Online]. Available: http://www.cdep.ru/index.php?id=79\&item=5460

12. M.A. Efimov, V.A. Shkurko, Retsidivnaya prestupnost i ee preduprezhdenie [Recidivism and its prevention] (Vysheyshaya shkola Publishing House, Minsk, 1977)

13. A.N. Sinyakov, Rus. J. Crim. 4, 28-35 (2020)

14. I.M. Rezhapova, I.M. Zaborovskaya, Person: Crime and Punish. 27(1), 40-46 (2019). https://doi.org/10.33463/1999-9917.2019.27(1-4).1.040-046

15. L.A. Latysheva, T.L. Muzychuk, M.G. Spasennikova, Rus. J. Crim. 1, 67-75 (2020). https://doi.org/10.17150/2500-4255.2020.14(1)

16. Challenge Incarceration Program (CIP). Accessed on: March 20, 2021. [Online]. Available: https://www.inmateaid.com/prisons/challenge-incarceration-program-cip3183

17. E. Herber, Int. J. Law, Crime and Just. 54, 102-110 (2018). https://doi.org/10.1016/j.ijlcj.2018.03.005

18. S.L. Clifasefi, H.S. Lonczak, S.E. Collins, Crime \& Delinquency, 63(4), 429-445 (2017). https://doi.org/10.1177/0011128716687550

19. S.E. Collins, H.S. Lonczak, S.L. Clifasefi, Eval. and Prog. Plan. 64, 49-56 (2017). https://doi.org/10.1016/j.evalprogplan.2017.05.008

20. Y. Zhao, S.F. Messner, J. Liu, Int. J. Law, Crime and Just. 63, art. 100425 (2020). https://doi.org/10.1016/j.ijlcj.2020.100425 
21. V.A. Ananich, S.Yu. Chasnok, Preduprezhdenie retsidivnoi prestupnosti [Prevention of recidivism] (Akad. of the Ministry of Internal Affairs of the Republic of Belarus Belarus, Minsk, 2008)

22. Kontseptsiya dolgosrochnogo sotsialno-ekonomicheskogo razvitiya Rossiiskoi Federatsii na period do 2020 goda (utverzhdena Rasporyazheniem Pravitelstva RF ot 17.11.2008 № 1662-r) [The concept of long-term socio-economic development of the Russian Federation for the period up to 2020 (approved by the Decree of the Government of the Russian Federation of 17.11.2008 No. 1662-r)]. Col. of Legislation of the RF 47, 5489 (2008)

23. I.Ya. Kozachenko, D.N. Sergeev, Rus. J. Crim. 2, 74-80 (2013)

24. A.Ya. Grishko, A.A. Chistyakov, E.S. Rakhmaev, et al., Predlozheniya po sovershenstvovaniyu mer po preduprezhdeniyu retsidivnoi prestupnosti v Rossiiskoi Federatsii [Proposals for improving measures to prevent recidivism in the Russian Federation] (Academy of FSIN of Russia, Ryazan, 2011)

25. Federalnyi zakon ot 06.04.2011 № 64-FZ “Ob administrativnom nadzore za litsami, osvobozhdennymi iz mest lisheniya svobody" [Federal Law No. 64-FZ dd. 06.04.2011 "On administrative supervision of persons released from places of deprivation of liberty"]. Accessed on: March 20, 2021. [Online]. Available: http://www.consultant.ru/document/cons_doc_LAW_112702/

26. Ukaz Prezidiuma Verkhovnogo Soveta SSSR ot 26.07.1966 № 5364-VI “Ob administrativnom nadzore organov vnutrennikh del za litsami, osvobozhdennymi iz mest lisheniya svobody" [Decree of the Presidium of the Supreme Soviet of the USSR dd. of 26.07.1966 No. 5364-VI "On Administrative supervision of internal affairs bodies over persons released from places of deprivation of liberty"], Vedomosti SS USSR 30, 597 (1966)

27. J. Byrne, G. Marx, Cahiers Politiestudies Jaargang, 3(20), 17-40 (2011) 